\title{
Yaupon Psyllid Gyropsylla ilecis (Ashmead) (Insecta: Hemiptera: Aphalaridae) ${ }^{1}$
}

Mark Wilhelm, Matthew Borden, and Adam Dale ${ }^{2}$

\section{Introduction}

The yaupon psyllid, Gyropsylla ilecis (Ashmead), is a native insect in the family Aphalaridae, order Hemiptera (Figure 1). The insect is inconspicuous during most of the year, but the leaf galls it produces in spring are readily observed. Nymphs feed on the new growth of yaupon holly, Ilex vomitoria, causing leaves to deform into a protective gall. The yaupon holly, native to the southeastern United States, is used as an ornamental tree or shrub and has also been used for centuries to produce a caffeinated, tea-like beverage. The yaupon psyllid is considered a minor aesthetic pest due to the unsightly presence of galls and some stunting of twigs. However, yaupon holly is rarely severely damaged by this insect.

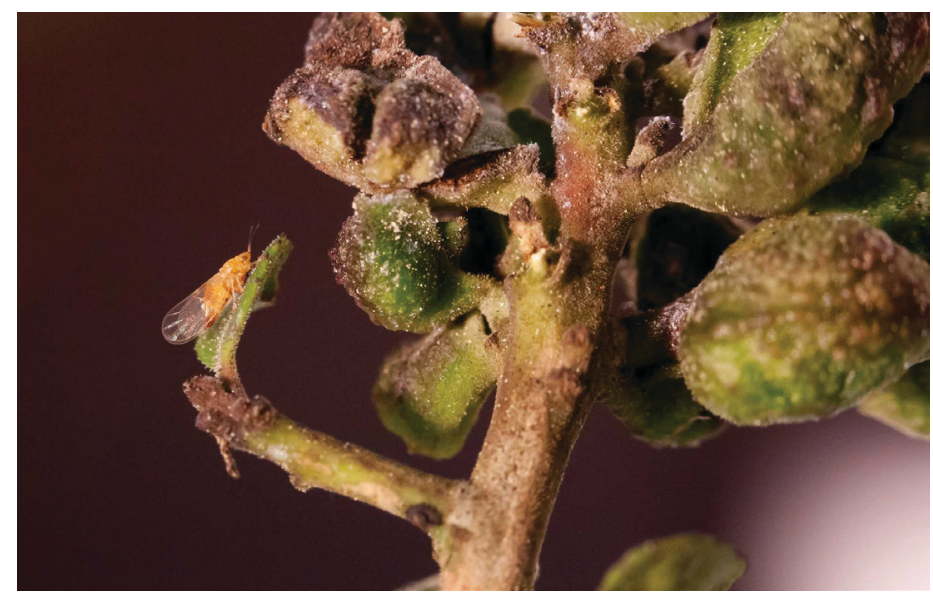

Figure 1. An adult yaupon psyllid, Gyropsylla ilecis (Ashmead) (left), with galls on yaupon holly, Ilex vomitoria.

Credits: Matthew Borden and Mark Wilhelm, UF/IFAS

\section{Synonymy}

Gyropsylla ilecis (Ashmead 1881) was originally described as Psylla ilecis Ashmead 1881. The scientific name is alternatively spelled as Gyropsylla ilicis (Ashmead 1881) and is also attributed to William Ashmead as Psylla ilicis. The spelling "ilecis" however, is used by more recent taxonomic authorities; hence the currently accepted name is Gyropsylla ilecis. Synonyms are listed below, which are the product of many taxonomic revisions placing this species into different genera (Ouvrard 2019).

Aphalara ilecis (Ashmead 1881)

Aphalara ilicis (Ashmead 1881)

Gyropsylla ilicis (Ashmead 1881)

Metaphalara ilecis (Ashmead 1881)

Metaphalara ilicis (Ashmead 1881)

Paurocephala ilecis (Ashmead 1881)

Paurocephala ilicis (Ashmead 1881)

Psylla ilecis Ashmead 1881

Psylla ilicis Ashmead 1881

\section{Distribution}

Gyropsylla ilecis can be found throughout much of the southeastern United States where its preferred host plant, yaupon holly, occurs (Mead 1983). This range extends from the coastal plains of North Carolina, south to Florida, and west to coastal eastern Texas (Johnson and Lyon 1991; observations from Houston, TX). In Florida, it is best

1. This document is EENY-736, one of a series of the Entomology and Nematology Department, UF/IFAS Extension. Original publication date August 2019. Visit the EDIS website at https://edis.ifas.ufl.edu for the currently supported version of this publication.

2. Mark Wilhelm; Matthew Borden; and Adam Dale; Entomology and Nematology Department, UF/IFAS Extension, Gainesville, FL 32611.

The Institute of Food and Agricultural Sciences (IFAS) is an Equal Opportunity Institution authorized to provide research, educational information and other services

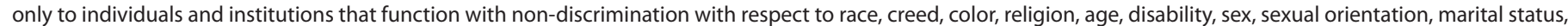

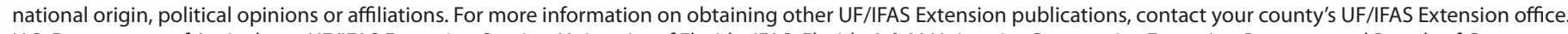
U.S. Department of Agriculture, UF/IFAS Extension Service, University of Florida, IFAS, Florida A \& M University Cooperative Extension Program, and Boards of County Commissioners Cooperating. Nick T. Place, dean for UF/IFAS Extension. 
known from numerous records in northern and northcentral counties (FDACS-DPI 2019).

\section{Description and Biology}

The adult yaupon psyllid is 5 to $6 \mathrm{~mm}$ (0.2 in) long and usually yellowish, although color varies from bright green to orange-red (Figure 2). Antennae are brown and threadlike. Adults have jumping legs and transparent wings held roof-like over their abdomens. Nymphs are flattened dorsoventrally and range from yellowish to orange-red. The abdomens of late instar nymphs may have a greenish tinge. They are often covered with a powdery white secretion which also lines their galls (Figure 3) (Mead 1983; Crawford 1914).

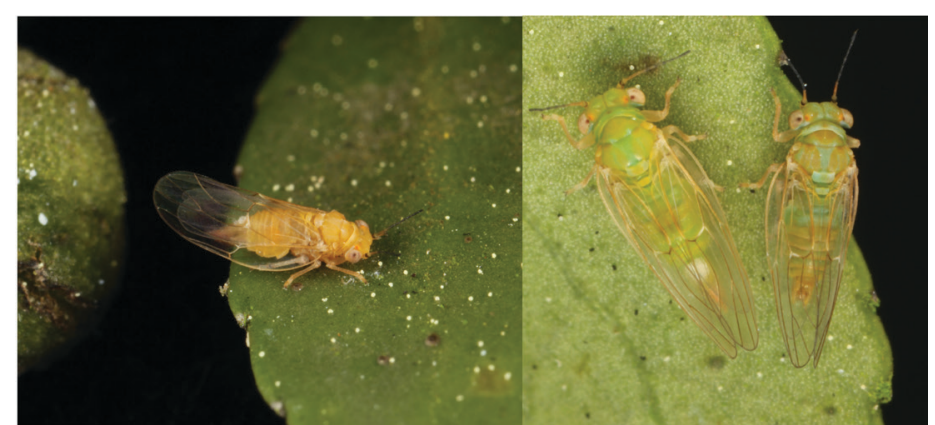

Figure 2. Adult Gyropsylla ilecis (Ashmead) showing color variation. Credits: Lyle Buss, UF/IFAS

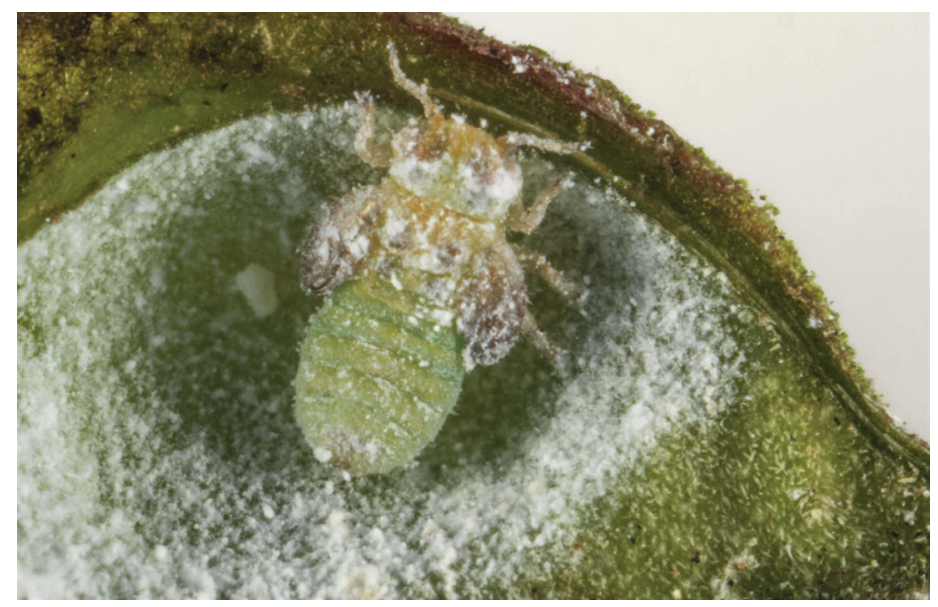

Figure 3. Gyropsylla ilecis (Ashmead) late-instar nymph with powdery residue inside a gall on Ilex vomitoria.

Credits: Lyle Buss, UF/IFAS

Adult female yaupon psyllids deposit eggs near leaf buds of new growth in spring, usually between February and March, with some eggs observed through April. Eggs are laid singly or in groups and begin whitish, but gradually turn yellow. They are pointed on one end and round on the other (Figures 4 and 5) (Mead 1983).

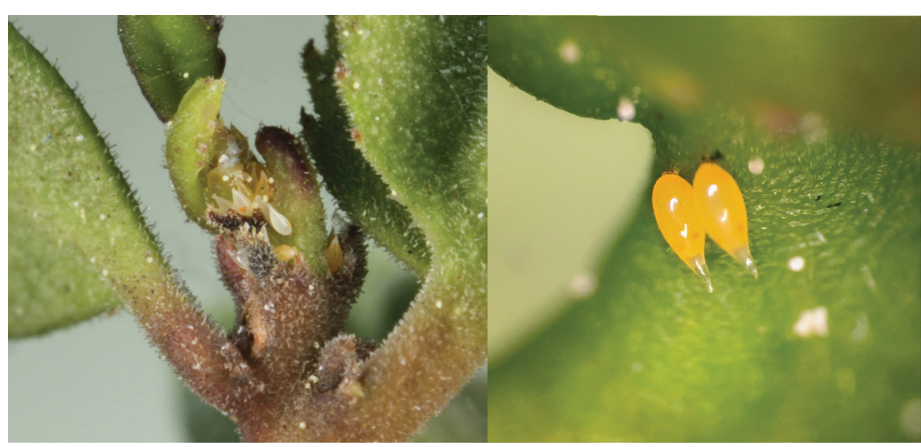

Figure 4. Eggs of Gyropsylla ilecis (Ashmead). The yellow color develops as eggs near hatching. The red eyes of the developing nymphs are just visible within the egg.

Credits: Lyle Buss (left) and Matthew Borden (right), UF/IFAS

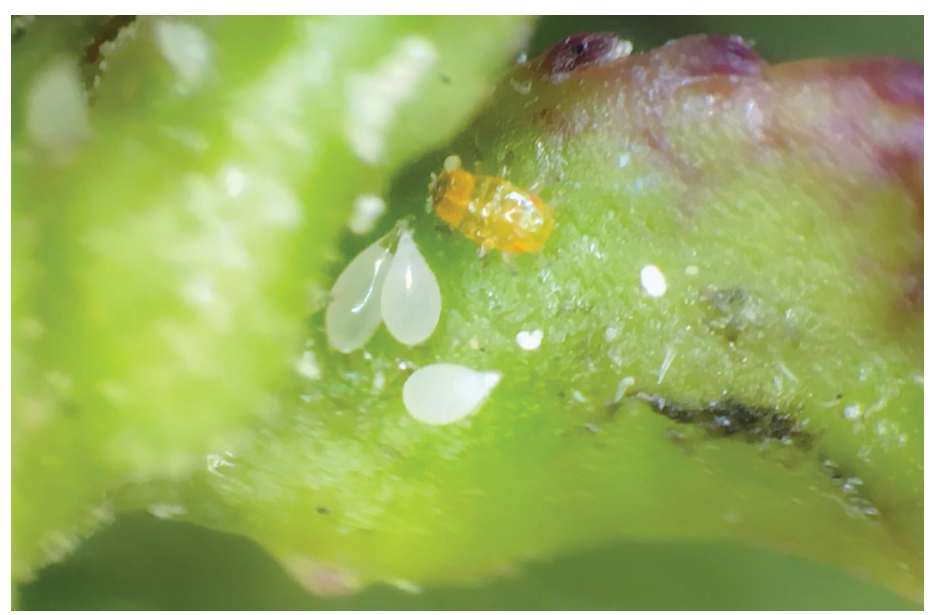

Figure 5. Gyropsylla ilecis (Ashmead) nymph and eggs on leaf bud. Credits: Matthew Borden, UF/IFAS

After hatching, nymphs begin feeding on sap from leaf buds (Figure 5) which causes the leaves to expand into galls (abnormal growths on plant tissue), forming a pocket when the leaf edges fold together around the psyllids.

Leaf galls seal tightly, concealing 1 to 19 individual yaupon psyllid nymphs inside and protecting them from predators and adverse weather conditions. The nymphs mature over the course of one year, passing through five instars (immature developmental stages). By summer in North Florida, most nymphs reach the 2 nd instar, and by November, 3 rd instar nymphs are most common. The 4 th instar nymphs dominate yaupon psyllid populations during the latter part of December, and by January of the following year, most of the nymphs have reached the 5 th, final instar. There is only one generation each year.

Once yaupon psyllid nymphs reach the final instar, the galls split open along the folded leaf margins, allowing the nymphs to exit and later molt to the adult stage (Figure 6). Adult psyllids can be found in Florida from mid-November to mid-April, with numbers peaking around February (Mead 1983). Phenology (timing of life stages) may vary slightly in other regions. 


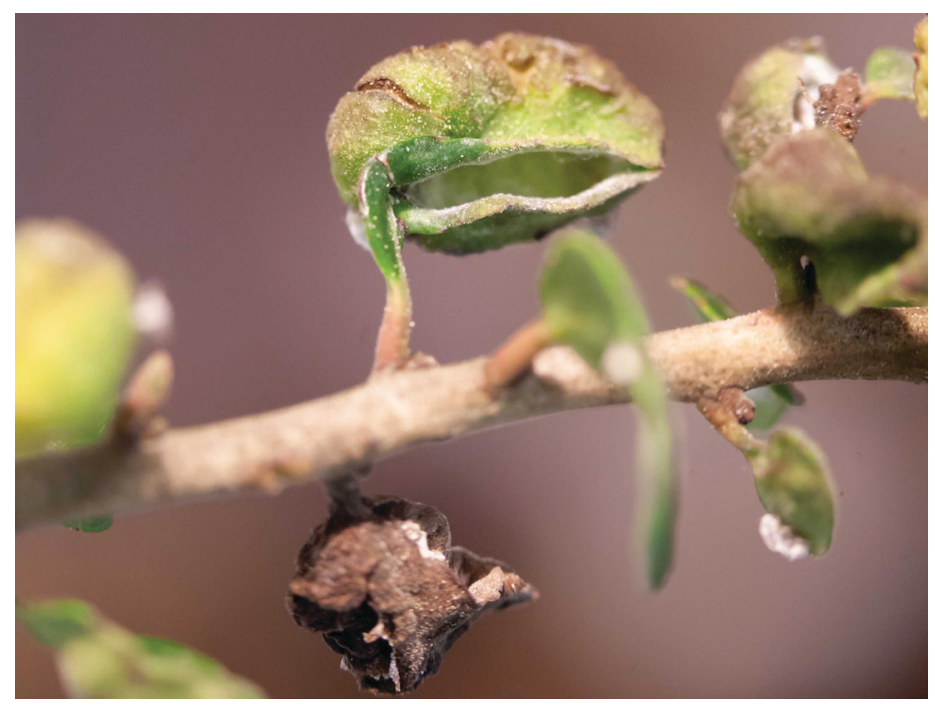

Figure 6. A recently opened leaf gall.

Credits: Matthew Borden, UF/IFAS

\section{Host}

As its name suggests, the yaupon psyllid feeds and reproduces on the yaupon holly, Ilex vomitoria. This plant is a prominent native species in coastal scrub and forest understory communities in the southeastern United States and is also grown as an ornamental tree or shrub. Yaupon holly is well known for its historical use by many indigenous peoples and early European settlers as a stimulating beverage (Hudson 1979) and is still harvested today to make yaupon tea, a caffeinated infusion (Palumbo et al. 2009; Wainwright and Putz 2014).

Mead (1983) reports Ilex vomitoria as the only known host plant for yaupon psyllid, which is the only psyllid known to form galls on the plant. Ashmead (1881) reports the psyllid galls on Ilex cassine; however, the early taxonomy of yaupon holly was highly inconsistent and inaccurate. The plant he observed was most likely Ilex vomitoria, known previously as Ilex cassine L. var. ß, among many similar names (Edwards and Bennett 2005; Hudson 1979). This is supported by the absence of observations of yaupon psyllid from the plant known today as Ilex cassine, the native dahoon holly.
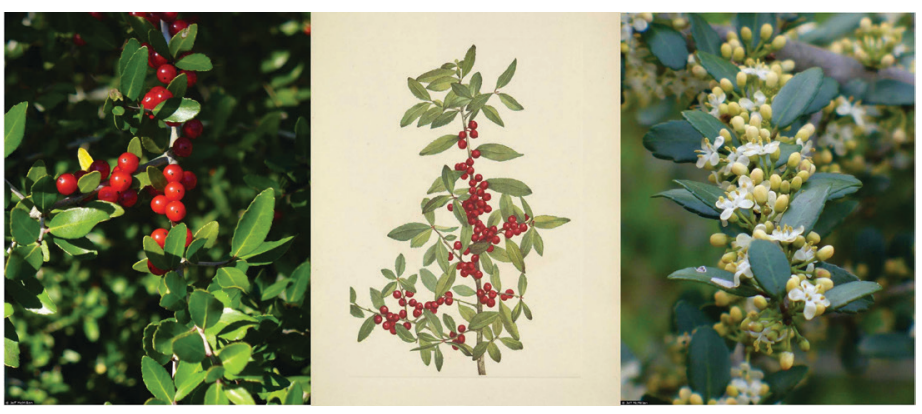

Figure 7. Yaupon holly, llex vomitoria Ait. Credits: Jeff McMillian, hosted by the USDA-NRCS PLANTS Database. Illustration: Mary Vaux Walcott, North American Wild Flowers, vol. 3 (1925)

\section{Economic Importance}

Yaupon psyllids cause the leaves of the yaupon holly to deform into galls, which may reach $14 \mathrm{~mm}$ (0.55 in) in length. The galls typically occur on the young growth near the tips of twigs. Galls are greenish when young and become purple to brown later in development, growing more wrinkled with age. The inside of each gall is lined with white powder or waxy material and contains nymph(s), shed skins (exoskeletons), and one or more droplets of honeydew. The damage caused to the plant is primarily aesthetic and control is generally not necessary (Mead 1983). Yaupon psyllid galls are rarely seen on dwarf cultivars of Ilex vomitoria, possibly due to their smaller leaf size, which may limit the psyllid's ability to create an inhabitable gall.

Galls are more frequently observed on wild type or weeping forms of Ilex vomitoria. Gall-forming psyllids in general are believed to induce gall formation through the saliva they inject while feeding. This saliva probably contains chemicals which cause the plant to form galls; however, little research has been done on these in psyllids. Besides protecting nymphs from predators and harsh environmental conditions, galls may increase the nutritional value of older leaves (Hodkinson 1984).

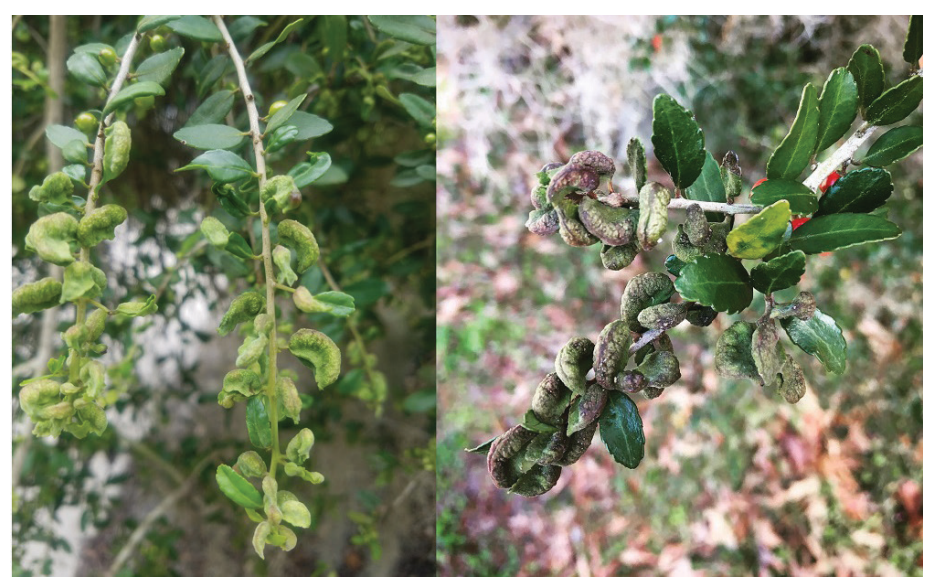

Figure 8. Younger, green galls on a weeping llex vomitoria (left), and older galls on a wild-type Ilex vomitoria, showing purplish coloration (right).

Credits: Nicole Benda and Matthew Borden, UF/IFAS

\section{Management}

Control is generally unnecessary for Ilex vomitoria planted in the landscape since the damage typically affects a small percentage of the plant canopy and is not known to reduce plant vigor. Twigs stunted by galling may be manually removed during routine pruning and shaping. Galls are not known to be a significant problem for yaupon tea producers, but may be worrisome for nursery growers or customers who rely on aesthetic quality and may mistake galls for a disease. If plants must be kept free of galls, it is critical to 
scout for the presence of adults over the winter and make foliar applications of appropriate insecticides to prevent egg laying or to target newly-hatched nymphs before galls begin to form.

\section{Selected References}

Ashmead WH. 1881. "On the Aphididae of Florida, with descriptions of new species [Family Psyllidae (jumping plant-lice)]." Canadian Entomology 13(11): 220-225.

Buckhardt D, Queiroz DL. 2013. "Phylogenetic relationships within the subfamily Aphalarinae including a revision of Limataphalara (Hemiptera: Psylloidea: Aphalaridae)." Acta Musei Moraviae, Scientiae Biologicae 98(2): 35-56.

Crawford DL. 1914. "A monograph of the jumping plantlice or Psyllidae of the New World." United States National Museum Bulletin 85: 1-186.

Edwards AL, Bennett BC. 2005. "Diversity of methylxanthine content in Ilex cassine L. and Ilex vomitoria Ait.: Assessing sources of the North American stimulant cassina." Economic Botany 59: 275-285.

Entomology Database. March 2019. Florida Department of Agriculture and Consumer Services, Division of Plant Industry.

Hodkinson ID. 1984. The biology and ecology of the gall-forming Psylloidea (Homoptera). In Ananthakrishnan TN (Ed.), Biology of gall insects, 59-77. New Delhi, India: Oxford \& IBH Publishing Co.

Hudson C. 1979. Black Drink: A Native American Tea. University of Georgia Press.

Johnson WT, Lyon HH. 1991. 2nd ed., rev. Insects that feed on trees and shrubs. Ithaca, NY: Cornell University Press.

Mead FW. 1983. "Yaupon psyllid, Gyropsylla ilicis (Ashmead)." Florida Department of Agriculture and Consumer Services, Division of Plant Industry, Entomology Circular No. 247:1-2.
Ouvrard D. 2019. Psyl'list: Psylloidea database (version Feb 2019). In: Species 2000 \& ITIS Catalogue of Life, 2019 Annual Checklist (Roskov Y., Ower G., Orrell T., Nicolson D., Bailly N., Kirk P.M., Bourgoin T., DeWalt R.E., Decock W., Nieukerken E. van, Zarucchi J., Penev L., eds.). Species 2000: Naturalis, Leiden, the Netherlands. ISSN 2405-884X. Available from: http://www.catalogueoflife.org/col/details/ species/id/149e18c4b53d6fcf4be6911cce309cf6 [13 June 2019].

Palumbo MJ, Talcott ST, Putz FE. 2009. "Ilex Vomitoria Ait. (Yaupon): A Native North American Source of a Caffeinated and Antioxidant-Rich Tea." Springer on behalf of New York Botanical Garden Press Sta. Economic Botany 63: 130-137.

USDA, NRCS. 2019. The PLANTS Database. National Plant Data Team, Greensboro, NC 27401-4901 USA. Available from: http://plants.usda.gov [18 April 2019].

Wainwright AE, Putz FE. 2014. "A misleading name reduces the marketability of a healthful and stimulating natural product: a comparative taste test of infusions of a native Florida holly (Ilex vomitoria) and yerba mate (I. paraguariensis)." Economic Botany 20(10): 1-5. 